\title{
Introduction of Macromolecules into Bovine Adrenal Medullary Chromaffin Cells and Rat Pheochromocytoma Cells (PC12) by Permeabilization with Streptolysin O: Inhibitory Effect of Tetanus Toxin on Catecholamine Secretion
}

\author{
Gudrun Ahnert-Hilger, *Marie-France Bader, †Sucharit Bhakdi, and Manfred Gratzl \\ Abteilung Anatomie und Zellbiologie der Universität Ulm, Ulm, F.R.G.; *Institut National de la Santé et de la Recherche \\ Médicale Unité U-44, Centre de Neurochimie du Centre National de la Recherche Scientifique, Strasbourg, France; \\ and †Institut für Medizinische Mikrobiologie der Universität Gießen, Gießen, F.R.G.
}

\begin{abstract}
Conditions are described for controlled plasma membrane permeabilization of rat pheochromocytoma cells (PC12) and cultured bovine adrenal chromaffin cells by streptolysin O (SLO). The transmembrane pores created by SLO invoke rapid efflux of intracellular ${ }^{86} \mathrm{Rb}^{+}$and $A T P$, and also permit passive diffusion of proteins, including immunoglobulins, into the cells. SLO-permeabilized PC1 2 cells release $\left[{ }^{3} \mathrm{H}\right]$ dopamine in response to micromolar concentrations of free $\mathrm{Ca}^{2+}$. Permeabilized adrenal chromaffin cells present a similar exocytotic response to $\mathrm{Ca}^{2+}$ in the presence of $\mathrm{Mg}^{2+}$ / ATP. Permeabilized PC12 cells accumulate antibodies against synaptophysin and calmodulin, but neither antibody reduces the $\mathrm{Ca}^{2+}$-dependent secretory response. Reduced tetanus toxin, although ineffective when applied to intact chromaffin
\end{abstract}

cells, inhibits $\mathrm{Ca}^{2+}$-induced exocytosis by both types of permeabilized cells studied. Omission of dithiothreitol, toxin inactivation by boiling, or preincubation with neutralizing antibodies abolishes the inhibitory effect. The data indicate that plasma membrane permeabilization by streptolysin $O$ is a useful tool to probe and define cellular components that are involved in the final steps of exocytosis. Key Words: Calmodulin-Catecholamine-secreting cells-Synaptophysin (p38)-Streptolysin O-Tetanus toxin. Ahnert-Hilger G. et al. Introduction of macromolecules into bovine adrenal medullary chromaffin cells and rat pheochromocytoma cells (PC12) by permeabilization with streptolysin O: Inhibitory effect of tetanus toxin on catecholamine secretion. $J$. Neurochem. 52, 1751-1758 (1989).
Permeabilization of secretory cells has become a widely used tool to investigate the mechanisms involved in the final events of exocytosis. Depending on the techniques applied, an effective dialysis of the cytoplasm can be obtained either for low molecular weight compounds [i.e., through generation of relatively small pores produced by high voltage discharges (Knight and Baker, 1982; Knight and Scrutton, 1986) or with staphylococcal $\alpha$-toxin (Ahnert-Hilger et al., 1985, 1987; Bader et al., 1986)] or for cytoplasmic proteins [i.e., by permeabilization with saponin (Brooks and Treml, 1983) and digitonin (Wilson and Kirshner, 1983; Peppers and Holz, 1986; Sarafian et al., 1987)].
Small pores (1-2 $\mathrm{nm}$ in diameter) in the plasma membrane are of advantage in studies on the requirements of monovalent or divalent cations, nucleotides, drugs, and other modulators of small size for exocytosis. The large lesions generated by saponin and digitonin induce efflux of cellular proteins (Sarafian et al., 1987) or may be used to introduce others. Successful permeabilization with digitonin has been reported for secretosomes from rat neurohypophysis (Cazalis et al., 1987), bovine chromaffin cells (Bader et al., 1986; Bittner et al., 1986; Grant et al., 1987) and also fragile pheochromocytoma cells (PC12) (Peppers and Holz, 1986; Ahnert-Hilger and Gratzl, 1987). An antibody
Received June 20, 1988; revised manuscript received September 6, 1988; accepted November 8, 1988.

Address correspondence and reprint requests to Dr. G. AhnertHilger at Abteilung Anatomie und Zellbiologie der Universität Ulm, Postfach 4066, D-7900 Ulm, F.R.G.
Abbreviations used: BSA, bovine serum albumin; DTT, dithiothreitol; HU, hemolytic unit; KG-buffer, potassium glutamate buffer; p38, synaptophysin; PIPES, 1,4-piperazinediethanesulfonic acid; SLO, streptolysin $\mathrm{O}$. 
against $\alpha$-fodrin introduced into digitonin-permeabilized bovine chromaffin cells reportedly inhibited $\mathrm{Ca}^{2+}$. induced exocytosis by these cells (Perrin et al., 1987).

Due to the detergent nature of digitonin and saponin, membrane permeabilization with these agents must be controlled carefully in order to be selective, i.e., restricted to the cell membrane. In the course of our efforts to circumvent problems which may arise from the unspecific attack of cellular membranes by the permeabilizing agent, we examined the possibility of using streptolysin $O$ (SLO) from $\beta$-hemolytic streptococci. This cytolysin produces large pores in target membranes (Duncan and Schlegel, 1975; Smyth and Duncan, 1978; Buckingham and Duncan, 1983; Bhakdi et al., 1985; Bhakdi and Tranum-Jensen, 1987) and has been used recently to permeabilize mast cells (Howell and Gomperts, 1987; Howell et al., 1987). We describe here a method for controlled plasma membrane permeabilization with SLO. The permeabilized catecholamine-secreting cells retain an intact exocytotic machinery, and antibodies to intracellular constituents, as well as tetanus toxin, can be introduced directly into these cells.

\section{MATERIALS AND METHODS}

Digitonin, dithiothreitol (DTT), calmidazolium, trifluoperazine, and ATP were from Sigma (München, F.R.G.). ${ }^{86} \mathrm{Rb}^{+}(1-8 \mathrm{mCi} / \mathrm{mg}$ ) was from Amersham Buchler (Braunschweig, F.R.G.) and $\left.{ }^{3} \mathrm{H}\right]$ dopamine $(30 \mathrm{Ci} / \mathrm{mmol})$ from New England Nuclear (Dreieich, F.R.G.). Antibody (rabbit) against synaptophysin (p38) was kindly provided by R. Jahn (MaxPlanck-Institut für Psychiatrie, Martinsried, F.R.G.). Goat antibody against calmodulin was a gift from $\mathrm{K}$. Gietzen (Abteilung Pharmakologie der Universität Ulm, F.R.G.). The peroxidase-antiperoxidase complex was from Dakopatts (Hamburg, F.R.G.). Tetanus toxin ( $\mathrm{ED}_{50}$ in mice: $6 \mathrm{ng} / \mathrm{kg}$ ) was a generous gift of U. Weller and E. Habermann (RudolfBuchheim-Institut für Pharmakologie, Universität Gießen, F.R.G.). Tetanus antitoxin from horse $(5,000 \mathrm{IU} / \mathrm{ml})$ was obtained from Behring Werke (Marburg, F.R.G.).

Purified SLO [200-250 hemolytic units (HU)/ $\mu \mathrm{g}$ of protein] was isolated as described previously (Bhakdi et al., 1984). The hemolytic activity of purified SLO preparation was assayed against $2.5 \%$ rabbit erythrocytes in $50 \mathrm{mmol} / \mathrm{L}$ phosphate-buffered saline supplemented with $1 \mathrm{mmol} / \mathrm{L}$. DTT (Lind et al., 1987). The dilution of SLO hemolyzing 50\% of the erythrocytes was taken as the number of HU per milliliter of the undiluted SLO solution (Lind et al., 1987). Experiments with bovine chromaffin cells were performed using SLOO obtained from Institut Pasteur (Paris, France).

PC12 cells were grown as described earlier (Ahnert-Hilger et al., 1985). Cells preloaded with $\left[{ }^{3} \mathrm{H}\right]$ dopamine for $2 \mathrm{~h}$ (Ahnert-Hilger and Gratzl, 1987) were washed twice in a $\mathrm{Ca}^{2+}$. free medium [in mmol/L: $\mathrm{NaCl}, 150 ; 1$,4-piperazinediethanesulfonic acid (PIPES), 10; EGTA, 1; pH 7.2] and once in $\mathrm{Ca}^{2+}$-free potassium glutamate buffer (KG-buffer) [in mmol/ L: potassium glutamate, 150; PIPES, 10; EGTA, 0.5; nitriloacetic acid, $5 ; \mathrm{pH} 7.2]$. The cells $\left(3-5 \times 10^{5} / \mathrm{sample}\right)$ were then suspended in KG-buffer supplemented with $0.1 \%$ bovine serum albumin (BSA). Permeabilization was achieved by incubating the PC12 cells with SLO $(60 \mathrm{HU} / \mathrm{ml})$ for $5 \mathrm{~min}$ on ice, followed by addition of ice-cold KG-buffer $(0.5 \mathrm{ml})$ and centrifugation. The supernatant was exchanged for fresh, icecold buffer supplemented with $\mathrm{Ca}^{2+}$ and the components to be tested. Release was initiated by transferring the samples to a water bath held at $30^{\circ} \mathrm{C}$ or $37^{\circ} \mathrm{C}$ for 10 or $20 \mathrm{~min}$.

Plasma membrane permeability was determined by measuring the release of cellular ${ }^{86} \mathrm{Rb}^{+}$or ATP. Release of ${ }^{86} \mathrm{Rb}^{+}$ from cells preloaded with the isotope, washed, and incubated in a $\mathrm{K}^{+}$-free balanced salt solution [containing (in $\mathrm{mmol} / \mathrm{L}$ ): $\mathrm{NaCl}, 150$; glucose, $10 ; \mathrm{CaCl}_{2}$, I; PIPES, $10 ; \mathrm{pH}$ 7.2] with the components to be tested was assayed as described previously (Ahnert-Hilger et al., 1985). ATP release was measured using the firefly assay obtained from Boehringer (Mannheim, F.R.G.) (Ahnert-Hilger and Gratzl, 1987; Lind et al., 1987). Prior to permeabilization, the cells were preincubated in a Ca ${ }^{2+}$-free balanced salt solution (in $\mathrm{mmol} / \mathrm{L}$ : $\mathrm{NaCl}, 150 ; \mathrm{KCl}, 5 ;$ glucose, $10 ;$ PIPES, $10 ; \mathrm{pH} 7.2$ ) containing $0.1 \% \mathrm{BSA}$ for $30 \mathrm{~min}$ at $30^{\circ} \mathrm{C}$. ATP release was followed in KG-buffer.

Bovine adrenal chromaffin cells $\left(5 \times 10^{5} /\right.$ well $)$ were prepared and permeabilized with $20 \mathrm{HU} / \mathrm{ml}$ SLO as described for $\alpha$-toxin (Bader et al., 1986), except that SLO incubation lasted $1 \mathrm{~min}$ (Sontag et al., 1988).

Experiments with tetanus toxin were always performed at $37^{\circ} \mathrm{C}$. Usually the permeabilized cells were preincubated with the toxin for $20 \mathrm{~min}$ in $\mathrm{Ca}^{2+}$-free KG-buffer containing 5 $\mathrm{mmol} / \mathrm{L} \mathrm{Mg}^{2+} / \mathrm{ATP}$ and $1 \mathrm{mmol} / \mathrm{L}$ free $\mathrm{Mg}^{2+}$ supplemented with 2-4 mmol/L DTT and $0.1 \% \mathrm{BSA}$. Then the cells were stimulated by adding $\mathrm{KG}$-buffer with $\mathrm{Ca}^{2+}$ containing neither DTT nor tetanus toxin. Experiments with intact cells were performed in a buffered physiological salt solution [containing (in $\mathrm{mmol} / \mathrm{L}$ ): $\mathrm{NaCl}, 140 ; \mathrm{KCl}, 4.7 ; \mathrm{Ca}^{2+}, 2.5 ; \mathrm{KH}_{2} \mathrm{PO}_{4}, 1.2$; $\mathrm{MgSO}_{4}, 1.2 ;$ glucose, 11 ; ascorbic acid, $0.56 ;$ HEPES, $15 ; \mathrm{pH}$ 7.4]. For stimulation, the $\mathrm{K}^{+}$concentration of this buffer was increased to $60 \mathrm{mmol} / \mathrm{L}$, whereas the $\mathrm{Na}^{+}$concentration was decreased to $80 \mathrm{mmol} / \mathrm{L}$.

The free $\mathrm{Ca}^{2+}$ concentrations in the media used were calculated by a computer program (Flodgaard and Fleron, 1974), kindly provided by T. Saermark (University of Copenhagen, Denmark), using the stability constants given (Sillen and Martell, 1971). The media were also controlled by a $\mathrm{Ca}^{2+}$ sensitive electrode (Simon et al., 1978). The neutral carrier incorporated into a polyvinyl chloride membrane was kindly provided by W. Simon (ETH Zürich, Switzerland).

Immunocytochemistry was performed as described (Schilling and Pilgrim, 1987) using the indirect antibody method (Sternberger, 1986). Antibodies G63 and G95 against rat synaptophysin (p38) were diluted 1:1,000 and anti-calmodulin antibody between 1:200 and 1:5,000.

\section{RESULTS}

$\mathrm{PC} 12$ cells loaded with ${ }^{86} \mathrm{Rb}^{+}$released this ion following their incubation with $\operatorname{SLO}(20 \mathrm{HU} / \mathrm{ml})$ at $30^{\circ} \mathrm{C}$ (not shown). At $0^{\circ} \mathrm{C}$, however, no SLO-mediated membrane permeabilization was noted at toxin doses up to $70 \mathrm{HU} / \mathrm{ml}$. At higher doses (above $70 \mathrm{HU} / \mathrm{ml}$ ), ${ }^{86} \mathrm{Rb}^{+}$release occurred even at low temperature (Fig. 1). When cells were first treated with SLO at $0^{\circ} \mathrm{C}$ for $10 \mathrm{~min}$, washed, and resuspended in buffer at $30^{\circ} \mathrm{C}$ for another 10 min without toxin, ${ }^{86} \mathrm{Rb}^{+}$release took place at $30^{\circ} \mathrm{C}$ with doses between 10 and $150 \mathrm{HU} / \mathrm{ml}$ (Fig. 1). These findings are consistent with previous results obtained with target erythrocytes (Hugo et al., 1986) and indicate initial binding of non-pore-forming toxin 


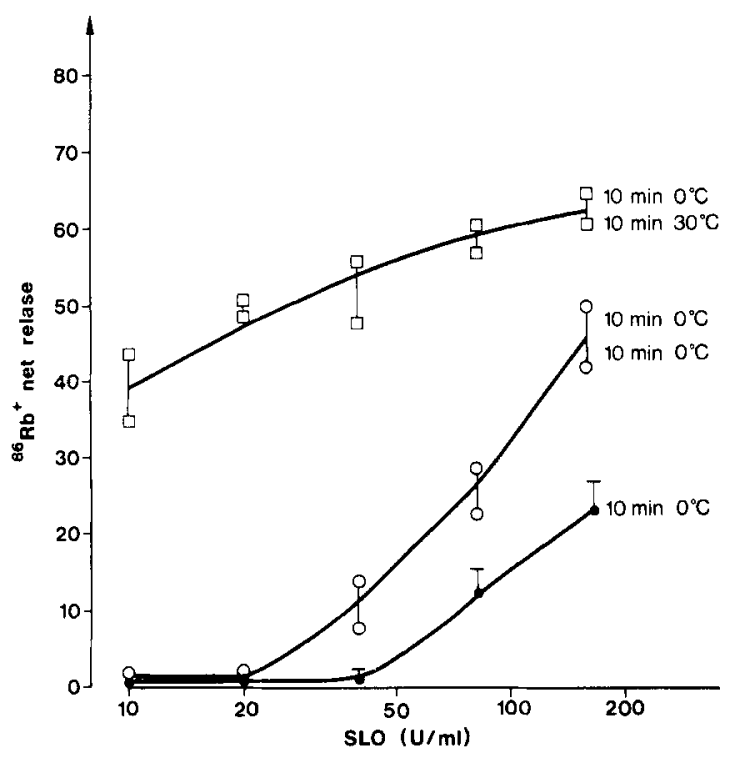

FIG. 1. Temperature dependence of ${ }^{86} \mathrm{Rb}^{+}$release from $\mathrm{PC} 12$ cells induced by SLO ${ }^{86} \mathrm{Rb}^{+}$-preloaded PC12 cells were subjected to the SLO concentrations shown on the abscissa at $0^{\circ} \mathrm{C}$ for $10 \mathrm{~min}$. Then the buffer was removed and counted for radioactivity. The incubation was continued for a further $10 \mathrm{~min}$ with fresh buffer without SLO either at $0^{\circ} \mathrm{C}$ or at $30^{\circ} \mathrm{C}$. Radioactivity was determined in the supernatant and the sodium dodecyl sulfate lysate of the cells. The experiment was performed on plates. The abscissa gives the final concentration of SLO. The basal release of ${ }^{86} \mathrm{Rb}^{+}(30.5$ $\pm 1 \% ; n=4$ ) was subtracted.

monomers at $0^{\circ} \mathrm{C}$, followed by rapid lateral aggregation and generation of pore-forming oligomers at $30^{\circ} \mathrm{C}$. Similar release data were obtained with cellular ATP, indicating an effective permeabilization of the cells for anions as well (Table 1). By contrast, digitonin released ${ }^{86} \mathrm{Rb}^{+}$(not shown) and ATP (Table 1) to a similar amount at $0^{\circ} \mathrm{C}$ or at $30^{\circ} \mathrm{C}$.

For membrane permeabilization in the successive experiments, it was thus optimal to incubate PC12 cells briefly with $20-60 \mathrm{HU} / \mathrm{ml} \mathrm{SLO}$ at $0^{\circ} \mathrm{C}$ and wash with cold buffer. $\left[{ }^{3} \mathrm{H}\right]$ Dopamine release experiments could then be conducted by resuspending the pelleted cells in prewarmed buffer $\left(30^{\circ} \mathrm{C}\right)$ containing the desired molecular components. $\mathrm{PC} 12$ cells permeabilized with SLO released large amounts of dopamine following the addition of $\mathrm{Ca}^{2+}$. Digitonin in a narrow range of concentration also permeabilized cells and rendered them sensitive to added $\mathrm{Ca}^{2+}$, although the $\mathrm{Ca}^{2+}$-stimulated release of dopamine was consistently lower (not shown).

The dependence of dopamine release on $\mathrm{Ca}^{2+}$ concentration is shown in Fig. 2. Here, cells were incubated for $5 \mathrm{~min}$ with $60 \mathrm{HU} / \mathrm{ml} \mathrm{SLO}$ at $0^{\circ} \mathrm{C}$ and then resuspended at $30^{\circ} \mathrm{C}$ in buffer containing increasing $\mathrm{Ca}^{2+}$ concentrations. Dopamine release was measured after $10 \mathrm{~min}$. The $\mathrm{Ca}^{2+}$ dependency observed indicated that PC1 2 cells permeabilized by SLO, as after permeabilization with $\alpha$-toxin (Ahnert-Hilger and Gratzl, 1987; Ahnert-Hilger et al., 1987), release dopamine by exo-
TABLE 1. Temperature dependence of ATP release by $S L O$ and digitonin from $P C 12$ cells

\begin{tabular}{lcc}
\hline & \multicolumn{2}{c}{ ATP released (\%) } \\
\cline { 2 - 3 } & $0{ }^{\circ} \mathrm{C}$ & $30^{\circ} \mathrm{C}$ \\
\hline KG-buffer & 16 & 12 \\
SLO $(100 \mathrm{HU} / \mathrm{ml})$ & 17 & 56 \\
Digitonin $(20 \mu \mathrm{mol} / \mathrm{L})$ & 50 & 60 \\
\hline
\end{tabular}

PCl 2 cells were incubated in a $\mathrm{Ca}^{2+}$-free balanced salt solution as described in Materials and Methods. The buffer was exchanged for KG-buffer supplemented with $0.1 \%$ BSA plus the indicated compounds, and the cells were either left on ice or incubated at $30^{\circ} \mathrm{C}$ for 10 min. After centrifugation, ATP was measured in the supernatant and in the extract of the cells as described (Lind et al., 1987). The experiment was conducted in duplicate. At the beginning of the experiment, total ATP content was $200 \mathrm{pmol} / 5 \times 10^{5}$ cells.

cytosis. Due to the larger size of the SLO pore, the introduction of large molecules into the cells is possible.

Two antibodies directed against intracellular cell components were tested for their ability to enter SLOpermeabilized $\mathrm{PC} 12$ cells. The first was an antibody against vesicular protein $\mathrm{p} 38$, which is present in intracellular vesicles of endocrine and neuronal cells (Rehm et al., 1986; Jahn et al., 1987; Navone et al., 1987; Schilling and Gratzl, 1988). The second was an antibody to calmodulin. Cells were permeabilized with $60 \mathrm{HU} / \mathrm{ml} \mathrm{SLO}\left(5 \mathrm{~min}, 0^{\circ} \mathrm{C}\right.$, followed by $10 \mathrm{~min}$ at $\left.30^{\circ} \mathrm{C}\right)$ or with digitonin $(20 \mu \mathrm{mol} / \mathrm{L})$ and then fixed with $4 \%$ paraformaldehyde. As positive controls, nonpermeabilized cells were first fixed and posttreated with

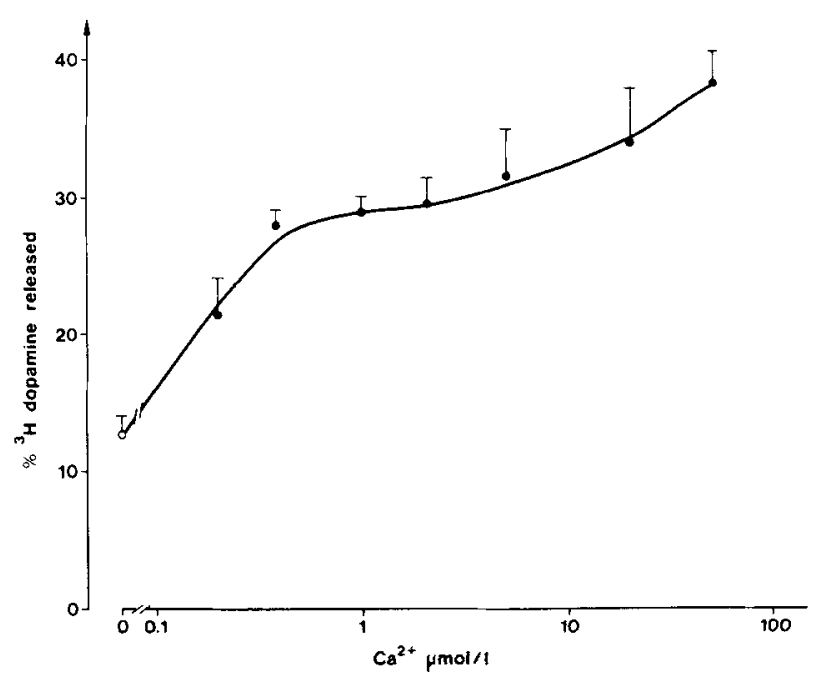

FIG. 2. $\left[{ }^{3} \mathrm{H}\right]$ Dopamine release by SLO-permeabilized $\mathrm{PC} 12$ cells as a function of the free $\mathrm{Ca}^{2+}$ concentration. Preloaded PC12 cells were treated as described in Materials and Methods. Cells were incubated with $60 \mathrm{HU} / \mathrm{ml} \mathrm{SLO}$ for $5 \mathrm{~min}$ at $0^{\circ} \mathrm{C}$. After a wash with KG-buffer, the cells were treated with the given amounts of free $\mathrm{Ca}^{2+}$ for $10 \mathrm{~min}$ at $30^{\circ} \mathrm{C}$. Radioactivity was counted in the supernatant and in the sodium dodecyl sulfate lysate of the cells. Each point represents the mean $\pm S D$ of three samples. 
$0.5 \%$ Triton $X-100$. The specimens were then incubated with antibodies, and bound immunoglobulins revealed with enzyme-labelled second antibodies. As shown in Figs. 3 and 4, nonpermeabilized cells did not take up anti-p38 or anti-calmodulin, respectively. However, cells permeabilized with both SLO and digitonin stained positively with these antibodies, and positive staining was also registered with Triton-treated cells. No staining was observed when anti-p38 was omitted.

When exocytosis by $\mathrm{PC} 12$ cells was triggered by 10 $\mu \mathrm{mol} / \mathrm{L}$ free $\mathrm{Ca}^{2+}$, we did not discern any effects evoked by either antibody despite their addition at low dilution to the incubation mix (Table 2). Similarly, the same antiserum against calmodulin, as well as the calmodulin antagonists trifluoperazine and calmidazolium (between 0.1 and $10 \mu \mathrm{mol} / \mathrm{L}$ ), did not affect exocytosis by SLO-permeabilized adrenal chromaffin cells elicited with $20 \mu \mathrm{mol} / \mathrm{L}$ free $\mathrm{Ca}^{2+}$ in the presence of $\mathrm{Mg}^{2+}$ / ATP (not shown).

In contrast, nanomolar concentrations of tetanus toxin inhibited the $\mathrm{Ca}^{2+}$-stimulated catecholamine release by adrenal medullary chromaffin cells, as well as by PC12 cells (Table 3, Fig. 5). Approximately 60\% inhibition was observed at $133 \mathrm{nmol} / \mathrm{L}$ toxin and 20 min incubation, corresponding to $26 \mathrm{pmol}$ or $3 \mathrm{pmol}$

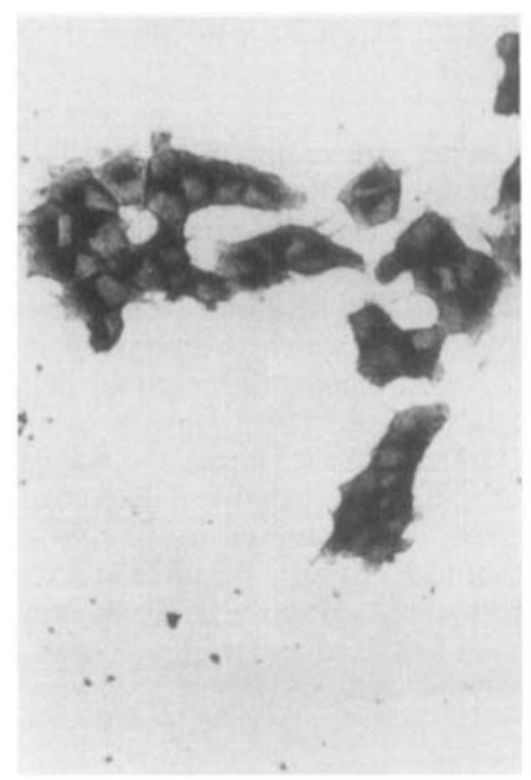

a

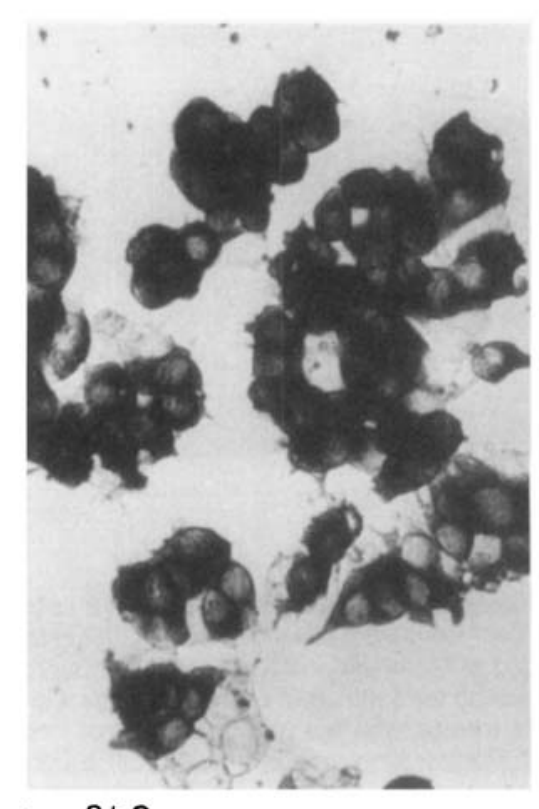

c SLO

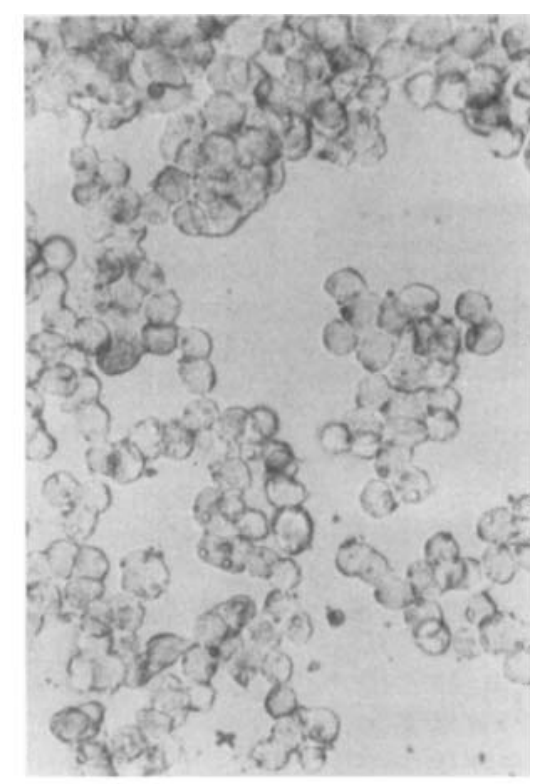

b non permeabilized

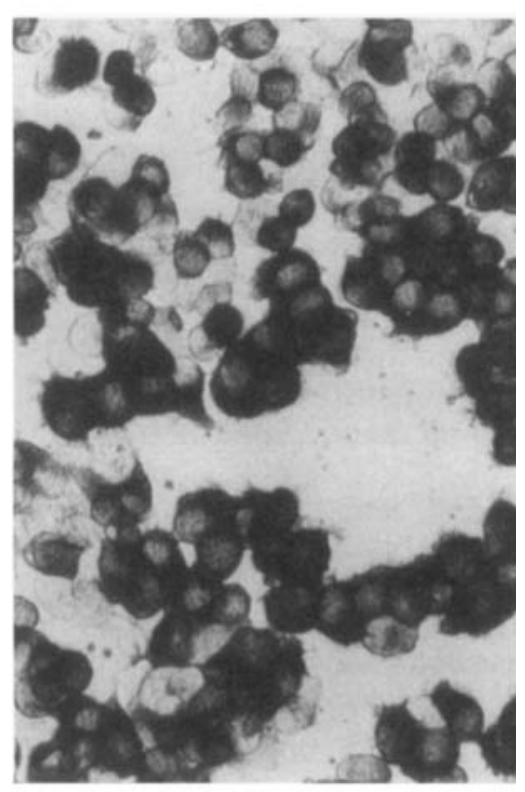

d digitonin
FIG. 3. Immunocytochemical detection of p38 in PC12 cells permeabilized by either digitonin or SLO. PC12 cells were washed twice with KG-buffer and then incubated for $10 \mathrm{~min}$ at $30^{\circ} \mathrm{C}$ in the same buffer without (b) or with $60 \mathrm{HU} / \mathrm{ml} \mathrm{SLO} \mathrm{(c)} \mathrm{or} 20 \mu \mathrm{mol} / \mathrm{L}$ digitonin (d). The incubation was stopped by fixing the cells with $4 \%$ paraformaldehyde. Immunocytochemistry was performed with $p 38$ antibody (final dilution $1: 1,000$ ). As a positive control, one batch of cells (a) was treated with Triton $x-100$ after fixation to make the intracellular antigen accessible to the antibody. 
FIG. 4. Immunocytochemical detection of calmodulin in PC12 cells permeabilized by either digitonin or SLO. The experimental protocol was the same as in Fig. 3. Immunocytochemistry was performed with the calmodulin antibody (final dilution 1:200). $\mathrm{a}$ : Triton X-100-treated positive control (final antibody dilution 1:1,000). b: Nonpermeabilized controls. c: SLO at $60 \mathrm{HU} / \mathrm{ml}$. d: Digitonin at $30 \mu \mathrm{mol} / \mathrm{L}$.
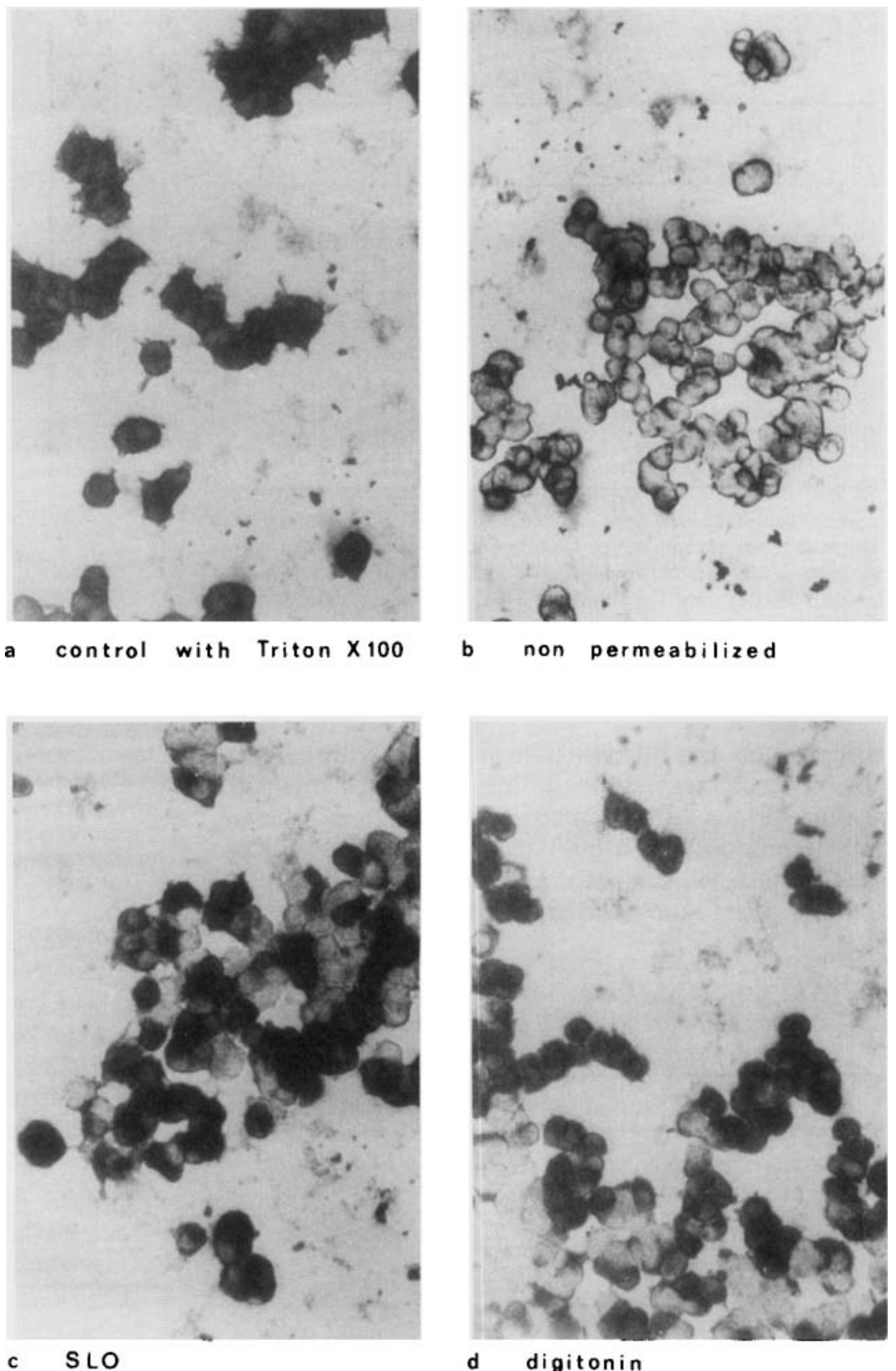

of tetanus toxin per sample of adrenal chromaffin or PC1 2 cells, respectively. The inhibitory effect of tetanus toxin increased with the time of incubation and approached $75 \%$ after 30 min (Table 4). Despite the different requirements of $\mathrm{Mg}^{2+} / \mathrm{ATP}$ for exocytosis in adrenal medullary chromaffin cells (Knight and Baker, 1982; Bader et al., 1986; Sontag et al., 1988) and PC12 cells (Ahnert-Hilger and Gratzl, 1987), the inhibitory effect of tetanus toxin was independent of the presence of ATP (not shown). Inhibition of $\mathrm{Ca}^{2+}$-induced exocytosis was observed only if cells were treated with tetanus toxin in the presence of DTT, and no effect was seen using native toxin. The reducing agent itself did not interfere with the exocytotic process. Inactivation of tetanus toxin by boiling (Table 3) or preincubation of the toxin with polyclonal antibodies (Fig. 5) nullified its inhibitory effects in both cell systems.

\section{DISCUSSION}

There is general agreement that the exocytosis machinery in neuronal and endocrine cells is regulated by intracellular $\mathrm{Ca}^{2+}$ levels. However, the mechanism of the final step triggered by $\mathrm{Ca}^{2+}$ and the role of other modulatory elements, such as calmodulin-linked enzymes, are not well understood. In order to elucidate the specific roles of $\mathrm{Ca}^{2+}$, as well as of the modulatory systems, controlled manipulation of the cytoplasmic 
TABLE 2. Effect of antibodies against calmodulin and p38 on $\mathrm{Ca}^{2+}$-induced $\left[{ }^{3} \mathrm{H}\right]$ dopamine release by $S L O$ permeabilized PC12 cells

\begin{tabular}{|c|c|}
\hline Treatment & $\begin{array}{c}\% \text { of }\left[{ }^{3} \mathrm{H}\right] \text { dopamine } \\
\text { released by } \mathrm{Ca}^{2+}\end{array}$ \\
\hline \multicolumn{2}{|l|}{$\mathbf{a}$} \\
\hline Buffer & $17.3 \pm 0.4$ \\
\hline Anti-calmodulin $(1: 500)$ & $21.2 \pm 1$ \\
\hline Anti-calmodulin $(1: 100)$ & $18.1 \pm 0.7$ \\
\hline Anti-calmodulin $(1: 20)$ & $15.1 \pm 1$ \\
\hline \multicolumn{2}{|l|}{ b } \\
\hline Buffer & $21 \pm 1.3$ \\
\hline Normal rabbit serum $(1: 20)$ & $15.3 \pm 3.8$ \\
\hline Anti-p38 G95 (1:20) & $17 \pm 1.8$ \\
\hline Anti-p38 G63 (1:20) & $22 \pm 1.9$ \\
\hline
\end{tabular}

Preloaded PC 12 cells were incubated with SLO for $5 \mathrm{~min}$ at $0^{\circ} \mathrm{C}$. The buffer was exchanged for fresh buffer and supplemented with the given antibodies plus or minus $10 \mu \mathrm{mol} / \mathrm{L}$ free $\mathrm{Ca}^{2+}$. The incubation was continued for $20 \mathrm{~min}$ at $37^{\circ} \mathrm{C}$. Values, obtained in two different experiments, are the means $\pm \mathrm{SD}$ of three samples. The release in the absence of $\mathrm{Ca}^{2+}$ (a: $32.3 \pm 1 \% ; \mathbf{b}: 31 \pm 1.4 \%$ ) was subtracted.

composition and introduction of primarily impermeable macromolecules, including antibodies directed against various cellular components or high molecular weight neurotoxins, would be highly desirable. Recently, mast cells permeabilized with SLO were shown to retain their exocytotic capacity (Howell and Gom-

TABLE 3. Dependence on DTT of the inhibition by tetanus toxin (Tetx) of [ $^{3} \mathrm{H}$ Inoradrenaline release from adrenal chromaffin cells

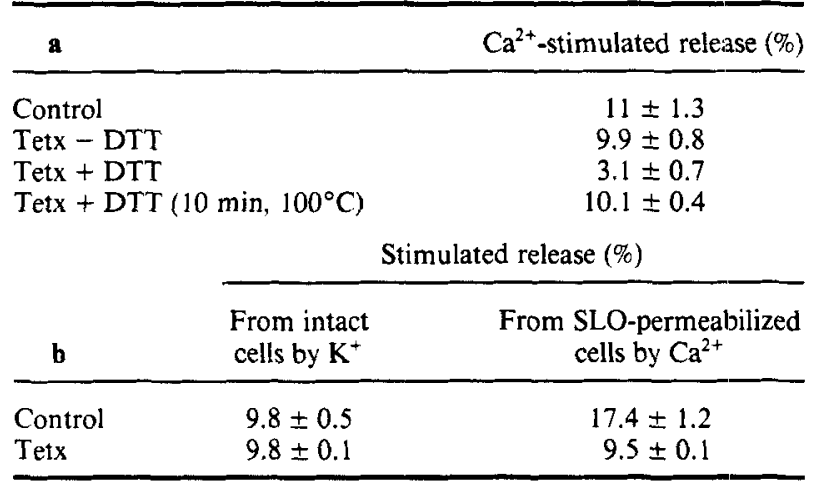

a: Preloaded adrenal medullary chromaffin cells were permeabilized and preincubated with $33 \mathrm{nmol} / \mathrm{L}$ Tetx for $20 \mathrm{~min}$ at $37^{\circ} \mathrm{C}$, as described in Materials and Methods. For stimulation $(10 \mathrm{~min})$, the buffer was replaced by fresh KG-buffer containing the same constituents plus $10 \mu \mathrm{mol} / \mathrm{L}$ free $\mathrm{Ca}^{2+}$. Basal release (in the absence of $\mathrm{Ca}^{2+}$ ) was $2.3 \pm 0.2 \%$. DTT, when present, was $4 \mathrm{mmol} / \mathrm{L}$.

b: Preloaded intact cells were incubated with buffered physiological salt solution containing $66 \mathrm{nmol} / \mathrm{L}$ Tetx and $4 \mathrm{mmol} / \mathrm{L}$ DTT for 20 $\min$ at $37^{\circ} \mathrm{C}$ before the stimulation with $60 \mathrm{mmol} / \mathrm{L} \mathrm{K} \mathrm{K}^{+}$. SLO-permeabilized cells were preincubated with Tetx in KG-buffer, as described in Materials and Methods, and stimulated with $37 \mu \mathrm{mol} / \mathrm{L}$ free $\mathrm{Ca}^{2+}$. Basal release was $3.8 \pm 0.3 \%$ from permeabilized cells and $2.4 \pm 0.3 \%$ from intact ones.

Values represent the stimulated $\left(\mathrm{Ca}^{2+}\right.$ or $\left.\mathrm{K}^{+}\right)$release of three samples \pm SD.

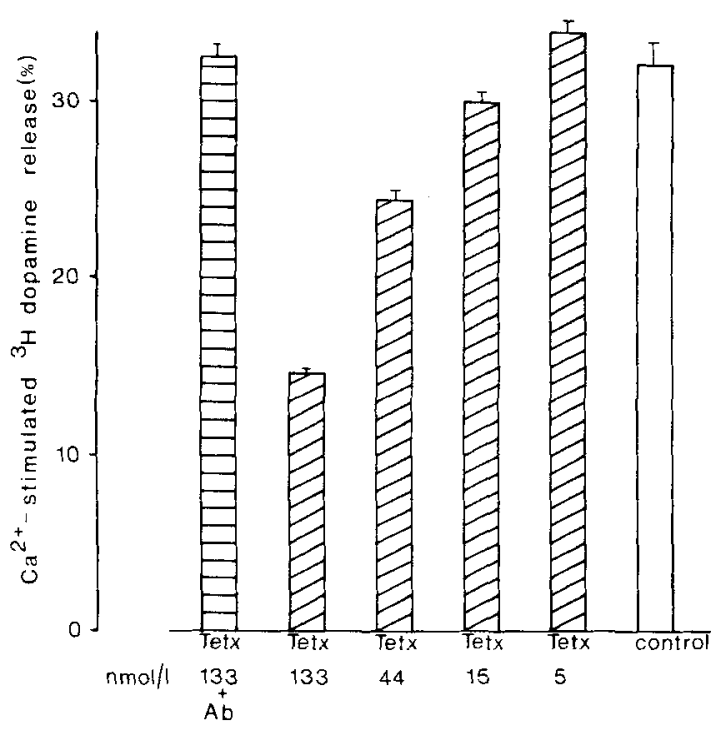

FIG. 5. Tetanus toxin (Tetx) inhibits $\mathrm{Ca}^{2+}$-induced $\left[{ }^{3} \mathrm{H}\right]$ dopamine release by SLO-permeabilized PC12 cells. Preloaded PC12 cells were permeabilized and preincubated with or without Tetx (final concentration between 133 and $5 \mathrm{nmol} / \mathrm{L}$ ) and $2 \mathrm{mmol} / \mathrm{L} \mathrm{DTT}$. For the antibody (Ab) control, $1.3 \mu \mathrm{mol} / \mathrm{L}$ Tetx was preincubated with $100 \mathrm{lU} / \mathrm{ml}$ tetanus antitoxin for $2 \mathrm{~h}$ at $37^{\circ} \mathrm{C}$ before it was diluted in KG-buffer with $2 \mathrm{mmol} / \mathrm{L}$ DTT. Cells were stimulated after 20 min by adding $\mathrm{Ca}^{2+}$ (final concentration $17 \mu \mathrm{mol} / \mathrm{L}$ ). The release in the absence of $\mathrm{Ca}^{2+}(15 \pm 1.2 \%)$ was subtracted. Values represent the $\mathrm{Ca}^{2+}$-stimulated release of three samples $\pm \mathrm{SD}$.

perts, 1987; Howell et al., 1987). The leakage of lactate dehydrogenase by these cells indicated that large pores had been created in their plasma membranes. The latter effect had been observed previously in PC12 cells (Ahnert-Hilger et al., 1985) and was consistent with the concept that SLO produces large transmembrane pores in target cells (Bhakdi et al., 1985; Bhakdi and Tranum-

TABLE 4. Time course of the effect of tetanus toxin (Tetx) on $\mathrm{Ca}^{2+}$-stimulated catecholamine release by $S L O$ permeabilized adrenal medullary chromaffin cells

\begin{tabular}{lccc}
\hline & \multicolumn{3}{c}{$\begin{array}{l}\mathrm{Ca}^{2+} \text {-stimulated catecholamine } \\
\text { release (\%) after preincubation }\end{array}$} \\
\cline { 2 - 4 } & $20 \mathrm{~min}$ & $30 \mathrm{~min}$ & $40 \mathrm{~min}$ \\
\hline a: Adrenal medullary & & & \\
$\quad$ chromaffin cells & & & \\
Control & 8.8 & 8.2 & 8 \\
Tetx $(66 \mathrm{nmol} / \mathrm{L})$ & 4.4 & 2.6 & 2.2 \\
b: PC12 cells & & & \\
Control & $21.7 \pm 1.1$ & ND & $10 \pm 0.3$ \\
Tetx $(13 \mathrm{nmol} / \mathrm{L})$ & $14.6 \pm 0.9$ & ND & $8.5 \pm 0.4$ \\
Tetx $(133 \mathrm{nmol} / \mathrm{L})$ & $10.2 \pm 0.9$ & ND & $4.2 \pm 0.1$ \\
\hline
\end{tabular}

Preloaded cells were incubated with SLO for $1 \mathrm{~min}$ at $37^{\circ} \mathrm{C}$ (a) or 5 min at $0^{\circ} \mathrm{C}($ b). Preincubation with Tetx was performed in fresh KG-buffer with $\mathrm{Mg}^{2+}, \mathrm{Mg}^{2+} / \mathrm{ATP}$, and DTT $(2 \mathrm{nmol} / \mathrm{L})$ for the given times at $37^{\circ} \mathrm{C}$. Cells were stimulated with a free $\mathrm{Ca}^{2+}$ concentration of $37 \mu \mathrm{mol} / \mathrm{L}$ (a) or $17 \mu \mathrm{mol} / \mathrm{L}$ (b). Release in the absence of $\mathrm{Ca}^{2+}$ (a: $2.2 \pm 0.5 \%$; b: $11.7 \pm 0.6 \%$ ) was subtracted. Values are the means of two (a) or three (b) samples. 
Jensen, 1987). We now report an improved experimental protocol for permeabilization of PC12 and adrenal medullary chromaffin cells with SLO which is based on previous experience obtained in the erythrocyte model (Hugo et al., 1986). Incubation of cells with low doses of SLO at $0^{\circ} \mathrm{C}$ results in initial toxinbinding without pore formation, and these cells can be washed and handled at low temperature prior to the exocytosis experiments. Permeabilization occurs rapidly upon postincubation at $30^{\circ} \mathrm{C}$, most probably due to formation of the pore-forming toxin oligomers by lateral aggregation. PC12 cells permeabilized in this fashion responded to $\mathrm{Ca}^{2+}$ stimulation with dopamine release similar to that observed in $\alpha$-toxin-permeabilized cells (Ahnert-Hilger and Gratzl, 1987; AhnertHilger et al., 1987). SLO-treated cells also accumulated antibodies against p38 and calmodulin. In these respects, permeabilization by SLO displayed similarities to that induced by digitonin. Although the antibodies to $p 38$ and calmodulin reached their respective intracellular antigens, $\mathrm{Ca}^{2+}$-stimulated exocytosis remained unaltered. p38 is an integral membrane protein associated with small clear vesicles in PC12 cells and secretory vesicles in other neuroendocrine cells (Rehm et al., 1986; Jahn et al., 1987; Navone et al., 1987; Schilling and Gratzl, 1988). Although there may be different functional pools of these proteins, the negative results obtained with anti-calmodulin are in accord with our previous negative results obtained with the calmodulin antagonist trifluoperazine in $\alpha$-toxin-permeabilized PC12 cells (Ahnert-Hilger and Gratzl, 1987). In contrast to our data, a possible role of calmodulin in adrenal medullary chromaffin cell secretion has been inferred from the effect of phenothiazines on intact cells (Kenigsberg et al., 1982; Brooks and Treml, 1984), as well as from a study where calmodulin antibodies were introduced into the cells using erythrocytes as vehicles (Kenigsberg and Trifaro, 1985).

Injection of tetanus toxin into adrenal medullary bovine chromaffin cells was reported recently to inhibit $\mathrm{Ca}^{2+}$-induced exocytosis as monitored by measurements of membrane capacitance (Penner et al., 1986). It was concluded that tetanus toxin, although ineffective when applied extracellularly (c.f. Habermann and Dreyer, 1986; see also Table 3 of this paper), can prevent exocytosis in chromaffin cells when injected directly into the cells. The present study extends these observations by showing that extracellularly applied tetanus toxin also inhibits exocytosis in chromaffin cells following their permeabilization by SLO. However, the effect is observed only when the toxin is applied in reduced form, and this requirement accounts for the negative results initially obtained with the use of native (unreduced) toxin (Ahnert-Hilger and Gratzl, 1988). It is noteworthy that the inhibitory effects of intracellularly applied toxin were noted after a relatively long lag period [60 min (Penner et al., 1986)], a finding that would be compatible with the necessity for intracellular processing of the molecule. Studies utilizing isolated toxin chains are currently under way to test the hypothesis that generation of a specific fragment might be required for tetanus toxin to exert its inhibitory effect on exocytosis. An inhibitory effect of tetanus toxin on $\mathrm{K}^{+}$-stimulated catecholamine release from intact PC12 cells has been reported; the prerequisite in this case was that the cells were pretreated with nerve growth factor (Figliomeni and Grasso, 1985). According to a recent report, nerve growth factor induces an increase of surface-exposed tri- and tetrasialogangliosides and, hence, a marked augmentation of tetanus-toxin binding to these cells (Walton et al., 1988). In light of the present observations and the results of Penner et al. (1986), the described effects of tetanus toxin on intact PC12 cells were due possibly to uptake of small amounts of toxin, which was applied in concentrations 1,000 times those used in the present study. In the same context, it is of interest to note that the concentrations of tetanus toxin used in our study were in the same range as those applied by Penner et al. (1986).

The present approach using SLO-permeabilized cells opens novel possibilities to analyze the molecular events underlying the action of neurotoxins and may help to delineate the mechanisms governing the exocytotic process in these cells.

Acknowledgment: The authors gratefully acknowledge the technical assistance of M. Rudolf, S. Keck, and D. Thiersé, as well as the secretarial help of B. Mader. We also thank U. Weller and E. Habermann for purified tetanus toxin and the determination of the toxicity in the used batches. This work was supported by the Deutsche Forschungsgemeinschaft $(\mathrm{Gr}$ 681 and $B h 2 / 2$ ), by Forschungsschwerpunkt No. 24 of the State of Baden-Württemberg, by the Verband der Chemischen Industrie, and by a twinning exchange PROCOPE fellowship.

\section{REFERENCES}

Ahnert-Hilger G. and Gratzl M. (1987) Further characterization of dopamine release by permeabilized PC12 cells. J. Neurochem. 49, 764-770.

Ahnert-Hilger G. and Gratzl M. (1988) Controlled membrane permeabilization by alpha-toxin and streptolysin $\mathrm{O}-$ tools to study the regulation of exocytosis. Naunyn-Schmiedeberg's Arch. Pharmacol. (suppl.) 337, 380 .

Ahnert-Hilger G., Bhakdi S., and Gratzl M. (1985) Minimal requirements for exocytosis: a study using PC12 cells permeabilized with staphylococcal alpha-toxin. J. Biol. Chem. 260, 1273012734.

Ahnert-Hilger G., Bräutigam M., and Gratzl M. (1987) Ca ${ }^{2+}$-stimulated catecholamine release from alpha-toxin-permeabilized PC 12 cells: biochemical evidence for exocytosis and its modulation by protein kinase $C$ and $G$ proteins. Biochemistry 26, 7842-7848.

Bader M. F., Thiersé D., Aunis D., Ahnert-Hilger G., and Gratzl M. (1986) Characterization of hormone and protein release from alpha-toxin-permeabilized chromaffin cells in primary culture. J. Biol. Chem. 261, 5777-5783.

Bhakdi S. and Tranum-Jensen J. (1987) Damage to mammalian cells by proteins that form transmembrane pores. Rev. Physiol. Biochem. Pharmacol. 107, 147-223.

Bhakdi S., Roth M., Sziegoleit A., and Tranum-Jensen J. (1984) Isolation and identification of two hemolytic forms of streptolysinO. Infect. Immun. 46, 394-400. 
Bhakdi S., Tranum-Jensen J., and Sziegoleit A. (1985) Mechanism of membrane damage by streptolysin-O. Infect. Immun. 47, 5260.

Bittner M. A., Holz R. W., and Neubig R. R. (1986) Guanine nucleotide effects on catecholamine secretion from digitonin-permeabilized adrenal chromaffin cells. J. Biol. Chem. 261, 1018210188 .

Brooks J. C. and Treml S. (1983) Catecholamine secretion by chemically skinned cultured chromaffin cells. J. Neurochem. 40, 468473.

Brooks J. C. and Treml S. (1984) Effect of trifluoperazine on catecholamine secretion by isolated bovine adrenal medullary chromaffin cells. Biochem. Pharmacol. 32, 371-373.

Buckingham L. and Duncan J. L. (1983) Approximate dimensions of membrane lesions produced by streptolysin-S and streptolysinO. Biochim. Biophys. Acta 729, 115-122.

Cazalis M., Dayanithi G., and Nordmann J. J. (1987) Requirements for hormone release from permeabilized nerve endings isolated from the rat neurohypophysis. J. Physiol. (Lond.) 390, 71-91.

Duncan J. L. and Schlegel R. (1975) Effect of streptolysin O on erythrocyte membranes, liposomes, and lipid dispersions. A proteincholesterol interaction. J. Cell Biol. 67, 160-173.

Figliomeni B. and Grasso A. (1985) Tetanus toxin affects the $\mathrm{K}^{+}$ stimulated release of catecholamines from nerve growth factortreated PC12 cells. Biochem. Biophys. Res. Commun. 128, 249256.

Flodgaard H. and Fleron B. (1974) Thermodynamic parameters for the hydrolysis of inorganic pyrophosphate at $\mathrm{pH} 7.4$ as a function of $\mathrm{Mg}^{2+}, \mathrm{K}^{+}$, and ionic strength determined from equilibrium studies of the reaction. J. Biol. Chem. 249, 3465-3470.

Grant N. J., Aunis D., and Bader M.-F. (1987) Morphology and secretory activity of digitonin- and alpha-toxin-permeabilized chromaffin cells. Neuroscience 23, 1143-1155.

Habermann E. and Dreyer F. (1986) Clostridial neurotoxins: handling and action at the cellular and molecular level. Curr. Top. Microbiol. Immunol. 129, 93-179.

Howell T. W. and Gomperts B. D. (1987) Rat mast cells permeabilized with streptolysin O secrete histamine in response to $\mathrm{Ca}^{2+}$ at concentration buffered in the micromolar range. Biochim. Biophys. Acta 927, 177-183.

Howell T. W., Cockcroft S., and Gomperts B. D. (1987) Essential synergy between $\mathrm{Ca}^{2+}$ and guanine nucleotides in exocytotic secretion from permeabilized rat mast cells. J. Cell Biol, 105, 191197.

Hugo F., Reichwein J., Brand M., Krämer S., and Bhakdi S. (1986) Use of a monoclonal antibody to determine the mode of transmembrane pore formation by streptolysin O. Infect. Immun. 54, 641-645.

Jahn R., Navone F., Greengard P., and DeCamilli P. (1987) Biochemical and immunocytochemical characterization of $\mathrm{p} 38$, an integral membrane glycoprotein of small synaptic vesicles. Ann. NY Acad. Sci. 493, 497-499.

Kenigsberg R. L. and Trifaró J. M. (1985) Microinjection of calmodulin antibodies into cultured chromaffin cells blocks catecholamine release in response to stimulation. Neuroscience 14, 335-349.

Kenigsberg R. L., Coté A., and Trifaró J. M. (1982) Trifluoperazine, a calmodulin inhibitor, blocks secretion in cultured chromaffin cells at a step distal from calcium entry. Neuroscience 7, 22772286.

Knight D. E. and Baker P. F. (1982) Calcium-dependence of catecholamine release from bovine adrenal medullary cells after exposure to intense electric fields. J. Membr. Biol. 68, 107-140.

Knight D. E. and Scrutton M. C. (1986) Gaining access to the cytosol: the technique and some applications of electropermeabilization. Biochem. J. 234, 497-506.

Lind I., Ahnert-Hilger G., Fuchs G., and Gratzl M. (1987) Purification of alpha-toxin from Staphylococcus aureus and application to cell permeabilization. Anal. Biochem. 164, 84-89.

Navone F., Jahn R., Gioia G., Stukenbrok H., Greengard P., and DeCamilli P. (1987) Protein p38: an integral membrane protein specific of small clear vesicles of neurons and neuroendocrine cells. J. Cell Biol. 103, 2511-2527.

Penner R., Neher E., and Dreyer F. (1986) Intracellularly injected tetanus toxin inhibits exocytosis in bovine adrenal chromaffin cells. Nature 324, 76-78.

Peppers S. C. and Holz R. W. (1986) Catecholamine secretion from digitonin-treated $\mathrm{PC} 12$ cells. Effects of $\mathrm{Ca}^{2+}, \mathrm{ATP}$, and protein kinase C activators. J. Biol. Chem. 261, 14665-14670.

Perrin D., Langley O. K., and Aunis D. (1987) Anti-alpha-fodrin inhibits secretion from permeabilized chromaffin cells. Nature 326, 498-501.

Rehm H., Wiedenmann B., and Betz H. (1986) Molecular characterization of synaptophysin, a major calcium-binding protein of the synaptic vesicle membrane. EMBO J. 5, 535-541.

Sarafian T., Aunis D., and Bader M.-F. (1987) Loss of proteins from digitonin-permeabilized adrenal chromaffin cells essential for exocytosis. J. Biol. Chem. 262, 16671-16676.

Schilling K. and Gratzl M. (1988) Quantification of p38/synaptophysin in highly purified adrenal medullary chromaffin vesicles. FEBS Lett. 233, 22-24.

Schilling K. and Pilgrim C. (1987) Hypothalamo-neurohypophysial neurons in vitro: developmental potentials depend on the donor rat stock. J. Neurosci. Res. 18, 432-438.

Sillen L. G. and Martell A. D. (1971) Stability Constants of MetalIon Complexes. Suppl. 1. The Chemical Society, London.

Simon W., Ammann D., Oehme M., and Morf W. E. (1978) $\mathrm{Ca}^{2+}$ selective electrodes. Ann. NY Acad. Sci. 307, 52-70.

Smyth C. I. and Duncan J. L. (1978) Thiol-activated (oxygen-labile) cytolysins, in Bacterial Toxins and Cell Membranes (Jeljaszewicz J. and Wadström T., eds), pp. 129-183. Academic Press, New York.

Sontag J. M., Aunis D., and Bader M.-F. (1988) Peripheral actin filaments control calcium-mediated catecholamine release from streptolysin-O-permeabilized chromaffin cells. Eur. J. Cell Biol. 46, 316-326.

Sternberger A. (1986) Immunocytochemistry, 3rd ed. John Wiley and Sons, New York.

Walton K. M., Sandberg K., Rogers T. B., and Schmaar R. L. (1988) Complex ganglioside expression and tetanus toxin binding by PC12 pheochromocytoma cells. J. Biol. Chem. 263, 2055-2063.

Wilson S. P. and Kirshner N. (1983) Calcium-evoked secretion from digitonin-permeabilized adrenal medullary chromaffin cells. $J$. Biol. Chem. 258, 4994-5000. 